\title{
HERBICIDINS C AND E, TWO NEW NUCLEOSIDE ANTIBIOTICS
}

\author{
Yo Takiguchi, Hiroji Yoshikawa, Akira Terahara, \\ Akio TORIKata and Michiya Terao \\ Fermentation Research Laboratories, Sankyo Co., Ltd. \\ 1-12-11, Tanashi, Tokyo, 188, Japan
}

(Received for publication July 9, 1979)

\begin{abstract}
Streptomyces saganonensis No. 4075 used for production of herbicidins A and B has also produced other two antibiotics, herbicidins $\mathrm{C}$ and $\mathrm{E}$ in submerged culture. Isolation of the antibiotics was performed by adsorption on resinous adsorbent followed by elution with aqueous $\mathrm{MeOH}$ and completed by silica-gel chromatography. Physico-chemical characterization revealed that herbicidins $\mathrm{C}$ and $\mathrm{E}$ are new nucleoside antibiotics having an adenine moiety in their structures. Herbicidins $\mathrm{C}$ and $\mathrm{E}$ indicated inhibitory activity against germination of chinese cabbage at $12.5 \mu \mathrm{g} / \mathrm{ml}$ and $25 \mu \mathrm{g} / \mathrm{ml}$, respectively, and Anacystis nidulans, a blue green algae, at $100 \sim 200 \mu \mathrm{g} / \mathrm{ml}$.
\end{abstract}

Herbicidins $\mathrm{A}$ and $\mathrm{B}^{1,2)}$, new nucleoside antibiotics with herbicidal activity, are produced by a strain belonging to Streptomyces saganonensis ${ }^{12}$ No. 4075, which has also produced other two minor components, herbicidins $\mathrm{C}$ and $\mathrm{E}$, simultaneously. The present paper describes the fermentation, isolation, and physical, chemical and biological properties of herbicidins $\mathrm{C}$ and $\mathrm{E}$.

\section{Materials and Methods}

Fermentation

The fermentation of $S$. saganonensis No. 4075 was performed for the production of herbicidins $\mathrm{C}$ and $\mathrm{E}$ in 600-liter fermentor containing 300 liters of a medium, which contains per liter, $20 \mathrm{~g}$ soluble starch, 80 g soybeanmeal, $10 \mathrm{~g}$ glucose, $10 \mathrm{~g} \mathrm{KH}_{2} \mathrm{PO}_{4}, 5 \mathrm{~g} \mathrm{NH}_{4} \mathrm{Cl}, 3 \mathrm{~g} \mathrm{CaCO}_{3}, 1 \mathrm{~g} \mathrm{ZnSO} \cdot 7 \mathrm{H}_{2} \mathrm{O}$, and $0.2 \mathrm{~g} \mathrm{MgSO}_{4} \cdot 7 \mathrm{H}_{2} \mathrm{O}$ (pH 6.5 before sterilization). Fifty liters of a good preculture was made by inoculating the broth cultured in shake flasks into a medium containing per liter, $20 \mathrm{~g}$ soluble starch, $20 \mathrm{~g}$ soybean meal, $10 \mathrm{~g}$ glucose, $10 \mathrm{~g} \mathrm{KH}_{2} \mathrm{PO}_{4}$ and $3 \mathrm{~g} \mathrm{CaCO}_{3}(\mathrm{pH} 6.5$ before sterilization). The incubation of the preculture was conducted in 100-liter fermentors, stirred at $200 \mathrm{rpm}$ and aerated at 50 liters per minute for 24 hours at $28^{\circ} \mathrm{C}$. Fifteen liters of the preculture was then inoculated to 300 liters of the fermentation medium, as described above. During the course of the 260 hours incubation period at $24^{\circ} \mathrm{C}$, dissolved oxygen was held at more than $2 \mathrm{ppm}$ in the broth of 600 -liter fermentor by agitation and aeration, and about $1 \%$ of residual glucose was kept in the culture broth by feeding the fermentor with $50 \%$ of glucose solution. The mycelial growth during fermentation was followed by the packed cell volume after centrifugation of $10 \mathrm{~g}$ of the broth at $3,000 \mathrm{rpm}$ for 10 minutes.

Assay procedure

The fermentation broth was tested for detection of herbicidins on silica gel TLC (Silica Gel 60 F-254, E. Merck, Darmstadt, Germany) using $\mathrm{CHCl}_{3}-\mathrm{MeOH}(7: 3)$ as a solvent system for development. Quantitative determination of each of herbicidins was performed by densitometry. The instrument used was Dual-Wavelength TLC Scanner (Model CS-900, Shimazu Co., Ltd., Japan) at $258 \mathrm{~nm}$. Each authentic sample was applied on the same plate with supernatants of the broth to be tested.

Isolation of herbicidins

Fermentation broth ( 400 liters) containing herbicidins was filtered with the aid of infusorial earth (Celite 545 from Johns-Manville Products Corp., Calif., U. S. A.). The filtrate (300 liters) was ad- 
sorbed on 30 liters of Diaion HP-20 (Absorbent resin from Mitsubishi-Kasei Co., Ltd., Japan) column. The spent broth and water washes (60 liters) contained very small amount of herbicidins were discarded. The adsorbate was washed with $10 \%$ aqueous $\mathrm{MeOH}$ again, and eluted with 100 liters of $50 \%$ aqueous $\mathrm{MeOH}$. The first 20 liters of the effluent contained herbicidin $\mathrm{C}$ and then herbicidins $\mathrm{A}$ and $\mathrm{B}$ were eluted with the successive 80 liters of the aqueous $\mathrm{MeOH}$. The fraction containing herbicidin $\mathrm{C}$ was concentrated in vacuo to 3 liters of aqueous layer, which was extracted twice each with 3 liters of $n$ $\mathrm{BuOH}$. The extract was concentrated to dryness in vacuo at $55^{\circ} \mathrm{C}$. Fifty grams of the crude solid thus obtained was dissolved in $60 \mathrm{ml}$ of $\mathrm{MeOH}$ to be applied to 2.5 liters of silica-gel column. The column was washed with 5 liters of $\mathrm{CHCl}_{3}$, eluted with a solvent system composed of $\mathrm{CHCl}_{3}$ and $\mathrm{MeOH}$ (9: 1) to remove herbicidins $\mathrm{A}$ and $\mathrm{B}$, and then developed with $\mathrm{CHCl}_{3}-\mathrm{MeOH}(8: 2)$ to elute herbicidin C. The fractions containing herbicidin $\mathrm{C}$ were combined and concentrated to dryness. The solid thus obtained was crystallized from $\mathrm{MeOH}$ yielding $2.5 \mathrm{~g}$ of herbicidin $\mathrm{C}$ as a colorless crystalline powder.

Herbicidin E was eluted from the adsorbate (Diaion HP-20) with 60 liters of $90 \%$ aqueous $\mathrm{MeOH}$ after the elution of herbicidins $\mathrm{A}$ and $\mathrm{B}$. The fractions containing herbicidin $\mathrm{E}$ were combined and concentrated in vacuo to 4 liters of water layer, which was extracted twice with each 4 liters of $\mathrm{CH}_{2} \mathrm{Cl}_{2}$. The extract was concentrated at $40^{\circ} \mathrm{C}$ in vacuo to give a yellowish syrup. Further purification was carried out by chromatography on silica gel column. The adsorbate was developed with a solvent system composed of $\mathrm{CHCl}_{3}$ and $\mathrm{MeOH}(98: 2)$. The fractions containing herbicidin $\mathrm{E}$ were combined and concentrated to dryness. The crude solid thus obtained was dissolved with $40 \mathrm{ml}$ of EtOAc and crystallized by addition of $n$-hexane, yielding $2.1 \mathrm{~g}$ of herbicidin $\mathrm{E}$ as colorless needles.

Inhibitory effect on growth of algae

The minimal inhibitory concentrations (MIC) of herbicidins C and E against Anacystis nidulans M-6, a blue green algae, was determined by conventional two-fold broth dilution method. The antibiotics were dissolved in acetone and added to MDM medium containing per liter; $100 \mathrm{mg} \mathrm{KNO}_{3}$, $25 \mathrm{mg} \mathrm{MgSO}{ }_{4} \cdot 7 \mathrm{H}_{2} \mathrm{O}, 25 \mathrm{mg} \mathrm{K}_{2} \mathrm{HPO}_{4}, 10 \mathrm{mg} \mathrm{NaCl}, 1 \mathrm{mg} \mathrm{CaCl} \cdot 2 \mathrm{H}_{2} \mathrm{O}, 0.1 \mathrm{ml} \mathrm{Fe}$ solution and $0.1 \mathrm{ml}$ $\mathrm{A}_{5}$ solution ( $\mathrm{pH}$ 8). Fe solution contains per liter; $2 \mathrm{~g} \mathrm{FeSO} \cdot 7 \mathrm{H}_{2} \mathrm{O}$, and 2 drops $\mathrm{H}_{2} \mathrm{SO}_{4}$. $\mathrm{A}_{5}$ solution contains per liter; $2.86 \mathrm{~g} \mathrm{H}_{3} \mathrm{BO}_{3}, 2.5 \mathrm{~g} \mathrm{MnSO}_{4} \cdot 7 \mathrm{H}_{2} \mathrm{O}, 222 \mathrm{mg} \mathrm{ZnSO}_{4} \cdot 7 \mathrm{H}_{2} \mathrm{O}, 79 \mathrm{mg} \mathrm{CuSO} \cdot 5 \mathrm{H}_{2} \mathrm{O}$, and $21 \mathrm{mg} \mathrm{Na}_{2} \mathrm{MoO}_{4}$. Cultivation of the algae was conducted in test tubes (diameter; $18 \mathrm{~mm}$ ) at $27^{\circ} \mathrm{C}$ under 1,500 lux for 16 hours a day and in dark for 8 hours a day. The MIC were examined after incubation of the test tubes for 2 weeks.

\section{Results and Discussion}

\section{Production}

Large-scale fermentations were conducted in 600-liter, stainless steel fermentation vessels. During the course of 260-hour incubation period, $\mathrm{pH}$ of the broth was kept in the range between 5.7 and 6.3. The packed cells volume in the broth increased in first 185 hours and then decreased gradually. Thin-layer chromatography on silica gel was employed to determine herbicidins production in the broth. The final broth of the fermentation contained herbicidins per liter; 4,500 mg A, $120 \mathrm{mg} \mathrm{B}, 80$ $\mathrm{mg} \mathrm{C}$ and $60 \mathrm{mg}$ E.

\section{Isolation}

The isolation method used for herbicidins is outlined in Fig. 1. For the first step purification, the resinous adsorbent, Diaion HP-20 was selected, because it gave a satisfactory separation of herbicidins each other and a satisfactory recovery of the antibiotics in the eluate. Separation of herbicidins from each other was completed on silica-gel column. Herbicidin $\mathrm{C}$ was recrystallized from $\mathrm{MeOH}$ to give crystalline powder. Herbicidin E was obtained from the eluate of silica-gel as colorless needles and recrystallized from EtOAc - $n$-hexane. 
Physical and Chemical Properties

Physico-chemical data is listed in Table 1. Herbicidin $\mathrm{C}$ is readily soluble in $\mathrm{MeOH}$ and $\mathrm{EtOH}$, soluble in acetone, but insoluble in $\mathrm{H}_{2} \mathrm{O}$, EtOAc and $n$-hexane. Herbicidin E is readily soluble in warm $\mathrm{H}_{2} \mathrm{O}$ and warm $\mathrm{MeOH}$, soluble in $\mathrm{H}_{2} \mathrm{O}$, $\mathrm{MeOH}, \mathrm{EtOH}$, acetone and EtOAc, but insoluble in $n$-hexane. Molecular weight of herbicidin E was derived from analysis of its FD mass spectrum. The IR and NMR spectra of herbicidins $\mathrm{C}$ and $\mathrm{E}$ are shown in Figs. 2, 3, 4 and 5, respectively.

Their physico-chemical properties, such as UV maxima at 259 $260 \mathrm{~nm}$, elementary analysis, two singlets due to heteroaromatic protons at $8.2 \sim 8.8 \mathrm{ppm}$ and a doublet due to one proton at $6.1 \sim 6.3 \mathrm{ppm}$ corresponding to the chemical shift of anomeric proton of usual nucleosides in NMR spectra, and fragment ion peak at 135 in FD mass spectrum, suggested adenine nucleoside moiety in the structures of both herbicidins $\mathrm{C}$ and $\mathrm{E}$.

From the results described above as well as from characteristic biological activities described below, one can conclude that herbicidins $\mathrm{C}$ and $\mathrm{E}$ are two new antibiotics with very closely related structures to herbicidins $\mathrm{A}$ and $\mathrm{B}^{2)}$.

Biological Properties

Antimicrobial activity of herbicidins $\mathrm{C}$ and $\mathrm{E}$ were tested with the method employed by ARAI et al. ${ }^{1)}$ There were no activity at $200 \mu \mathrm{g} / \mathrm{ml}$ of either herbicidins $\mathrm{C}$ and $\mathrm{E}$ against all of the microorganisms, such as Staphylococcus aureus FDA 209P(JC-1), Escherichia coli NIHJ(JC-2), Mycobacterium smegmatis ATCC 607, Pseudomonas aeruginosa SANK 73575, Proteus rettgeri SANK 73775, Klebsiella pneumoniae PCI 602, Serratia marcescens SANK 73060, Bacteroides fragilis SANK 71176, Bacillus
Fig. 1. Isolation and purification of herbicidins $\mathrm{C}$ and $\mathrm{E}$.

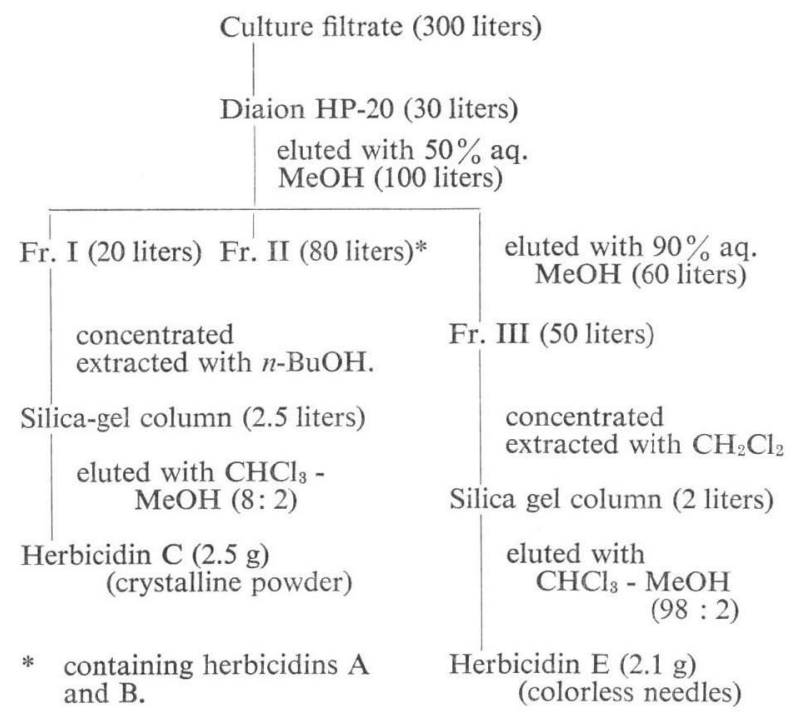

Table 1. Physico-chemical properties of herbicidins $\mathrm{C}$ and $\mathrm{E}$.

\begin{tabular}{|c|c|c|}
\hline & Herbicidin C & Herbicidin E \\
\hline Nature & $\begin{array}{l}\text { White crystalline } \\
\text { powder }\end{array}$ & $\begin{array}{l}\text { Colorless needle } \\
\text { crystals }\end{array}$ \\
\hline Solubility & $\begin{array}{l}\text { Soluble in } \mathrm{MeOH} \text {, } \\
\text { EtOH, acetone }\end{array}$ & $\begin{array}{l}\text { Soluble in } \mathrm{H}_{2} \mathrm{O} \text {, } \\
\text { EtOH, acetone, } \\
\text { EtOAc. }\end{array}$ \\
\hline Melting point & $165 \sim 169^{\circ} \mathrm{C}$ (dec.) & $172 \sim 173^{\circ} \mathrm{C}$ \\
\hline \multirow{3}{*}{$\begin{array}{l}\text { M.W. } \\
\text { Elementary } \\
\text { analysis }\end{array}$} & \multirow{3}{*}{$\begin{array}{l}\text { Found } \\
\qquad \mathrm{C}, 46.47 ; \mathrm{H}, 4.82 \\
\quad \mathrm{~N}, 15.94 \%\end{array}$} & 537 \\
\hline & & $\begin{array}{l}\text { Found } \\
\quad \mathrm{C}, 50.50 ; \mathrm{H}, 5.58 \\
\quad \mathrm{~N}, 13.12 \%\end{array}$ \\
\hline & & $\begin{array}{l}\text { Calcd for } \\
\mathrm{C}_{23} \mathrm{H}_{30} \mathrm{~N}_{5} \mathrm{O}_{10}(536.53) \\
\mathrm{C}, 51.44 ; \mathrm{H}, 5.63 ; \\
\mathrm{N}, 13.04 \%\end{array}$ \\
\hline $\mathrm{Rf}^{*}$ & 0.30 & 0.69 \\
\hline$U V_{\max }\left(E_{1 \mathrm{~cm}}^{1 \%}\right)$ & $\begin{array}{l}259 \mathrm{~nm} \text { in } \\
\mathrm{MeOH}(300)\end{array}$ & $\begin{array}{l}260 \mathrm{~nm} \text { in } \\
\mathrm{MeOH}(270)\end{array}$ \\
\hline
\end{tabular}

* Merck, DC-Fertigplatten Kieselgel $60 \mathrm{~F}_{254} \quad\left(\mathrm{CHCl}_{3}\right.$ $\mathrm{MeOH}, 7: 3$ ) 
Fig. 2. Infrared spectrum of herbicidin $\mathrm{C}(\mathrm{KBr})$.

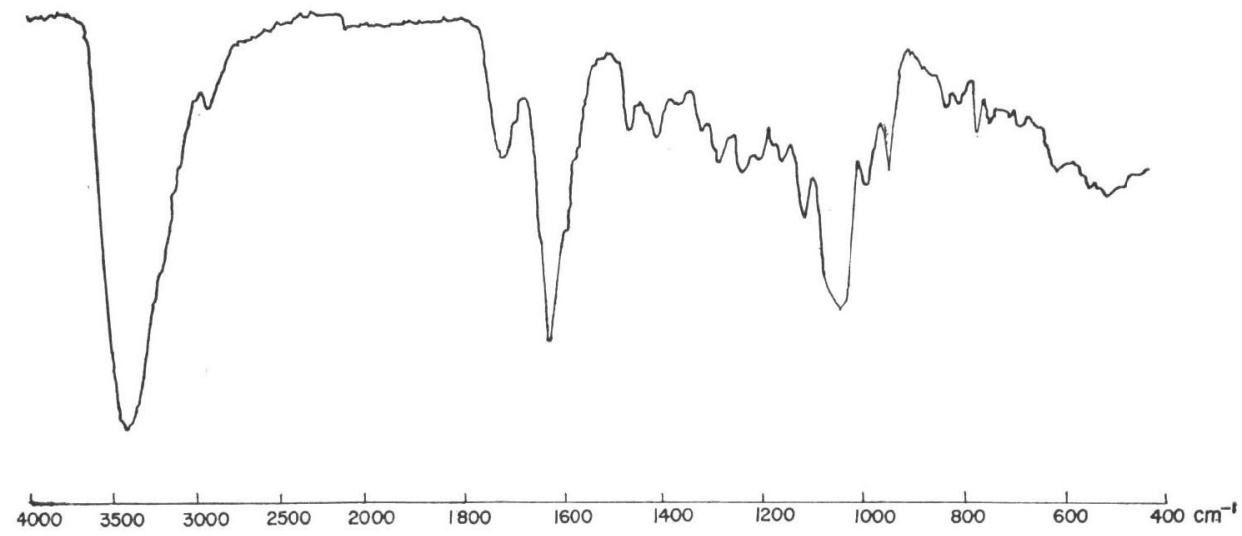

Fig. 3. Infrared spectrum of herbicidin $\mathrm{E}(\mathrm{KBr})$.

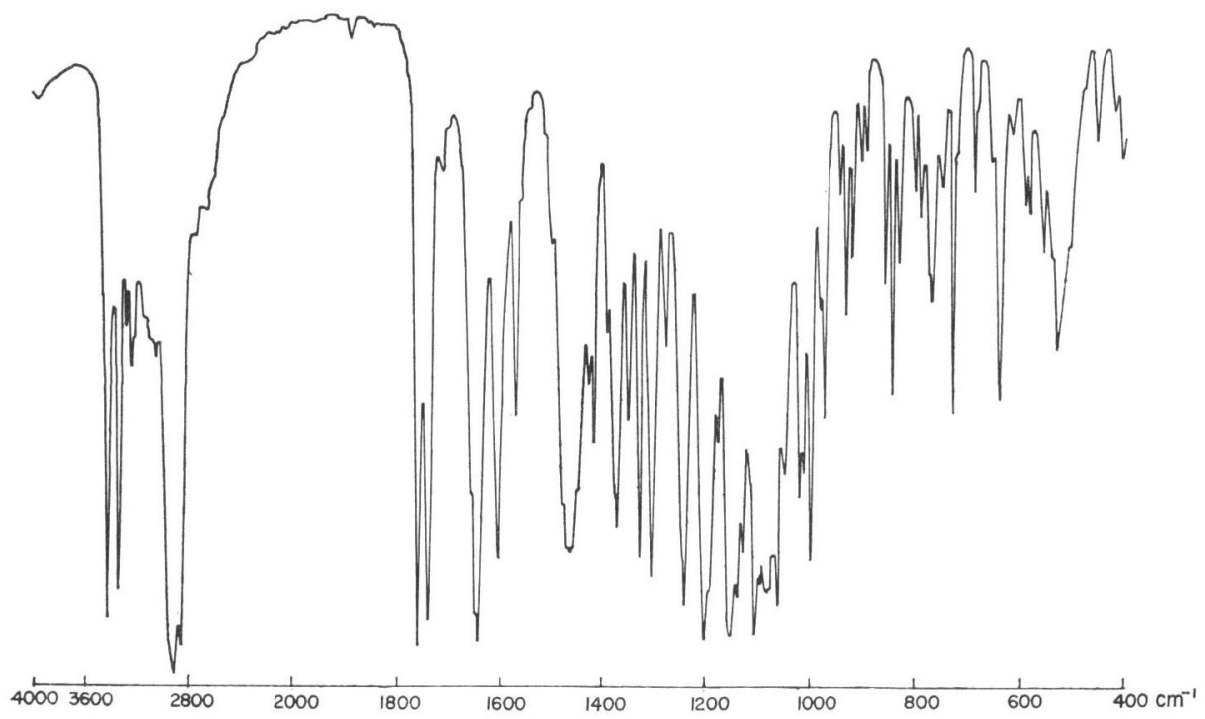

subtilis PCI 219, Candida albicans SANK 50157, Trichophyton mentagrophytes SANK 11868, and Pyricularia oryzae SANK 14958.

However, both herbicidins $\mathrm{C}$ and $\mathrm{E}$ gave inhibitory effects on growth of algae. The minimal inhibitory concentrations of both herbicidins $\mathrm{C}$ and E against Anacystis nidulans M-6, a blue green algae, were $100 \mu \mathrm{g} / \mathrm{ml}$ and $100 \sim 200 \mu \mathrm{g} / \mathrm{ml}$, respectively.

More potent inhibitory effect of herbicidins $\mathrm{C}$ and $\mathrm{E}$ occurred against germination of the plant seeds, such as chinese cabbage, when determined by the method reported from our laboratories ${ }^{1)}$. The minimal inhibitory concentrations of herbicidins $\mathrm{C}$ and $\mathrm{E}$ for the germination were 12.5 and 25 $\mu \mathrm{g} / \mathrm{ml}$, respectively.

Herbicidal activities of the antibiotics will be reported elsewhere. 
Fig. 4. NMR spectrum of herbicidin $\mathrm{C}$ tetraacetate in $\mathrm{CDCl}_{3}(60 \mathrm{MHz})$.

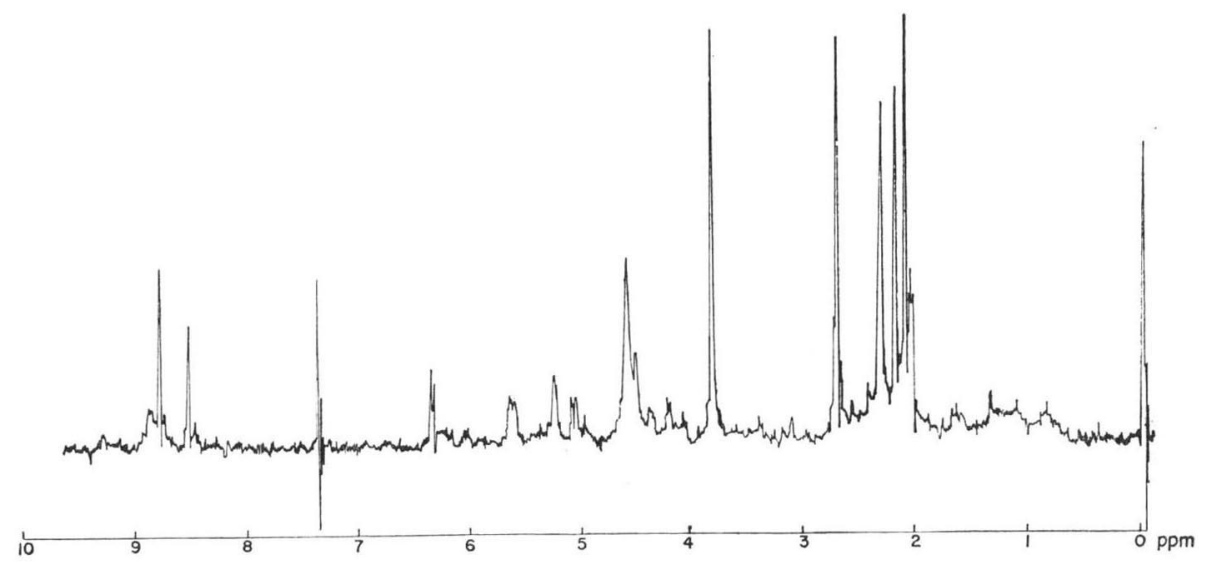

Fig. 5. NMR spectrum of herbicidin $\mathrm{E}$ in $\left(\mathrm{CD}_{3}\right)_{2} \mathrm{CO}$ and $\mathrm{CD}_{3} \mathrm{OD}(100 \mathrm{MHz})$.

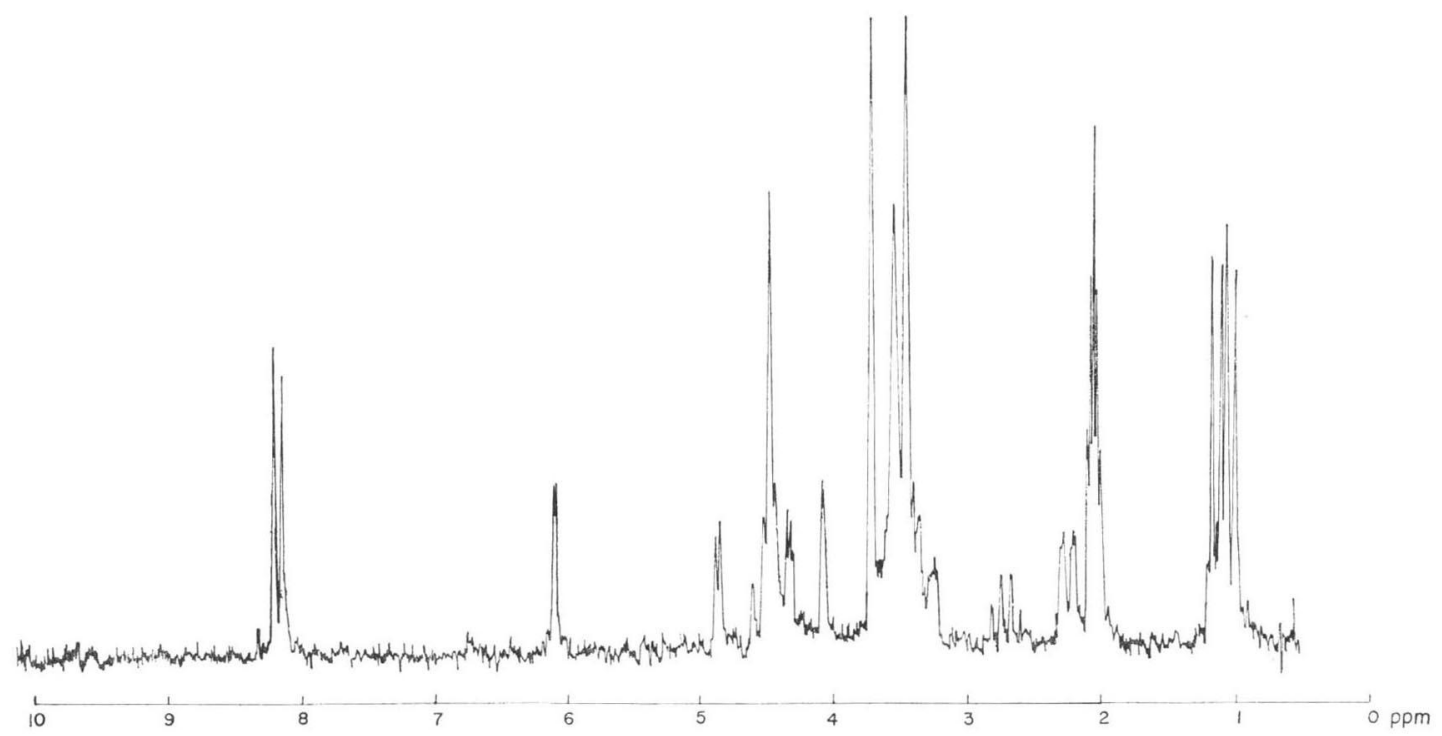

\section{References}

1) Arai, M.; T. Haneishi, N. Kitahara, R. Enokita, K. Kawakubo \& Y. Kondo: Herbicidins A and B, two new antibiotics with herbicidal activity. I. Producing organism and biological activities. J. Antibiotics 29: 863 869, 1976

2) Haneishi, T.; A. Terahara, H. Kayamori, J. Yabe \& M. Arai: Herbicidins A and B, two new antibiotics with herbicidal activity. II. Fermentation, isolation and physico-chemical characterization. J. Antibiotics 29: 870 875, 1976 